\title{
Modal Verbs Hedging: The Uses and Functions of "Will" and "Shall" in Nigerian Legal Discourse
}

\author{
Ibrahim Bashir ${ }^{1}$, Kamariah Yunus ${ }^{1} \&$ Tamer Mohammed Al-Jarrah ${ }^{2}$ \\ ${ }^{1}$ Universiti Sultan Zainal Abidin (UniSZA), 21300 Kuala Nerus, Terengganu, Malaysia \\ ${ }^{2}$ Universiti Malaysia Terengganu (UMT), 21300 Kuala Nerus, Terengganu, Malaysiata \\ Correspondence: Kamariah Yunus, Centre of English Language Studies, Faculty of Languages and \\ Communication, Universiti Sultan Zainal Abidin (UniSZA), 21300 Kuala Nerus, Terengganu, Malaysia. E-mail: \\ kamariah@unisza.edu.my
}

Received: May 23, 2018 Accepted: June 20, 2018 Online Published: November 27, 2018

doi:10.5539/ijel.v8n7p59 URL: https://doi.org/10.5539/ijel.v8n7p59

\begin{abstract}
This is a corpus-based study on the uses and functions of modal verbs "will" and "shall" in the Nigerian legal discourse. It aims at examining their pragmatic functions as hedges in the legal discourse. It specifically aims to investigate how hedges are used in the legal texts to indicate precision and uncertainty. To achieve these objectives a specialised corpus was constructed which we named as "Nigerian Law Corpus" (NLC). The compilation of NLC is based on the Nigerian court proceedings and law reports. Hence, the compiled NLC corpus contains 546,313-word tokens. Meanwhile, reference corpus of law with 2.2 million word tokens based on the British National Corpus (BNC) is retrieved for comparison with NLC. To this end, two concordance tools were utilised to analyse the data of this study viz. "AntConc version 3.5" a semi-automated computer-aided tool and a web-based tool "Lextutor version 7". Based on the frequency distribution the results revealed that model verb "will" featured in 493 instances in the NLC and 7,711 instances in the BNC Law, while, "shall" occurred at 401 instances in NLC and 1,348 instances in BNC Law. The results also indicated that "shall" was an overused element in NLC than in BNC Law with standardised concordance hits per million (NLC=734, BNC Law $=589$ ) while, "will" is the least used element of NLC (902 instances per million) compared to BNC Law (3,369 instances per million). The study also enumerated different semantic and pragmatic functions of "will" and "shall" in legal discourse, citing examples from both tag corpus (NLC) and reference corpus (BNC Law). Some of the functions as hedges (conveying a truth value of a proposition) are epistemic meanings: politeness, obligation, precision, duty, intention, and permission. In nutshell, the results indicated that "will" and "shall" are used by legal practitioners more especially lawyers in a courtroom to achieve precision in their argument in a case to persuade the court by showing the true value of commitment of the proposition.
\end{abstract}

Keywords: corpus analysis, epistemic modality, English for Specific Purposes (ESP), legal phraseology, hedges, modality

\section{Introduction}

The ever greater interest of linguists more especially the corpus linguists, terminologists, phraseologists and the text linguists or stylists has been centred on the exploration of distinctive characteristics of language used in different discourses and across the various genres. These can be sum up to form a language used in a specialized discourse. Hence, the study of language use in a specialized discourse is predominantly regarded as the study of linguistic features (lexis, syntax, semantics and context of use) of language used in special genre such as law, technology, business, or professional and institutional settings, such as hospitals, schools, and the courts (Rahman, 2015; Yunus, Mohamad, \& Waelateh, 2016). And of course, language as a medium of communication is central to the law as Gibbons (2013) construes that trials are linguistics events and the law is inconceivable without language. Therefore, the legal processes are intrinsically bound up with language (Holland \& Webb, 1993).

Moreover, the terminologists use the term "legalese" referring to a specialised form of English language used in the legal profession. This is the kind of a language construes in accordance to the law of countries where English is spoken as a native language (NL) like England, Australia, and America, as well as some other countries whose official language is English like Nigeria, Ghana, and India. Legalese is characterised as a special jargon, full of 
abstract concepts, whose meanings are strained, obscured, and sometimes complex, normative or even ambiguous and inaccessible to the laymen (Ashipu \& Umukoro, 2014). It is a discourse full of substantial complex grammatical structures, specialised lexis and archaic expressions marked with limited punctuation, which together make it different from other varieties (Sharndama \& Jauro, 2014).

It is equally important to acknowledge the crucial roles played by the English language in Nigeria not only for the colonial tie with Great Britain but due to the complex and complicated ethnolinguistic nature of Nigerian societies with people speaking about 400 different languages (Ibrahim, Yusof, Ahamd, \& Omar, 2016). Therefore, English is adopted as the official language in the Nigerian Language policy and used for wider communicative purposes. Obviously, it was for political socio-cultural reasons that favoured English at Nigerian national level, despite having three strong indigenous languages at regional level including, the Hausa language is most widely spoken in the northern region and almost two-third of Nigerian population can speak it; the Yoruba language is the second language mostly spoken in the southern region of Nigeria, while the Igbo language is the spoken in the eastern region of Nigeria (Kamal, 2010). Henceforth, English is used as the legal lingua franca in Nigeria, it is the language of the court, irrespective of the language spoken by the judge, the litigants, the court's officials or the lawyers. That is why any document not written in English must first be translated into the English language before it can be accepted (admitted) by the court because the Nigerian Courts from the High Court to the Supreme Court invariably conduct their entire businesses in English.

However, there are indeed linguistic challenges which posed disparity between legal practitioners and laymen or even among the legal practitioners themselves, in Nigeria when using English as legal lingua Franca. Such as the issues of specialised terminologies, translation the from continental language as Mattila (2016) postulates that when using English as a lingua franca especially in legal activities, the issue of translatability is compounded, due to the nature of the concepts used in English common law that is different to some extent with terminologies that are used in continental language. Moreover, a corpus-based approach is considered as one of the less explored areas of studies of legal texts ((Biel, 2017; Yunus, Su'ad, \& Rashid, 2016; Kjær, 2007). This may be due to the nature of the legal lexicons which assume to be an unproductive style of language (Mellinkoff, 1963; Danet, 1980; Bhatia, 1987). Meanwhile, in the Nigerian context, the legal English is seemed to be least explored with very few studies available. Very few use corpora as a method of analysis.

Furthermore, for over four decades, English modality has received significant consideration from the area such as synchronic, diachronic and variation linguistic perspectives (Suzuki, 2018). Correspondingly, Kennedy (2002) considers the claim made by F. R. Palmer (1979) as the laying foundation for the importance of modal verbs in English language. Palmer (1979) postulates that "there is perhaps, no area of English grammar that is both more important and more difficult than the system of modals" (p. 1). Likewise, the norm in most of the studies of modality since 1970's is primarily centred on the exploration of semantics uses and functions of modal verbs. Since then a rich data were analysed and illustration was made by many researchers. Moreover, the interest on the study of modality is revived with the evolution of modern electronic corpora which "make it possible to explore the nature and use of linguistic phenomena in a much wider variety of texts" (Kennedy, 2002, p. 73). Such descriptions go beyond investigating what is grammatically and semantically possible but encompass a distributional dimension which marks the distinctive features of a language in terms of probability of occurrence. Corpus-based studies also make it possible to extend our understanding of language use across different genres in different linguistic domains.

This present study explores the uses and functions of two modal verbs (will and shall) as a form of hedges, and their frequency of occurrence in Nigerian Legal Corpus (NLC 546,313) in comparison with British National Corpus (BNC Law 2.2). Hedging plays important roles in nuancing language in such language oriented disciplines as law (Vass, 2017). The better understanding of hedging use in different discourse can enhance hedging competence, and improve the communicative competence, especially the interpretation of hedging uses in different genres. To bridge the gap of communication barrier a pragmatic knowledge of using hedges is necessary (Ahmed \& Maros, 2017). Hedges are important agents in legal language, putting forth the nature of legal discourse as discipline notably preoccupied with politeness, persuasion, and vagueness in the use of language.

\subsection{The Concept of Hedging}

The term "hedging" is a complex area of linguistics studies obviously concerns with linguistics aspects such as pragmatics, semantics, logic and language philosophy (Schoroder \& Zimmer, 1997). Hedges are specialized linguistic elements initially proposed by Lakoff (1972) from a purely semantic perspective in his article hedges: a study in meaning criteria and logistic of fuzzy concepts. Lakoff's article reflects the developing prototype 
theory of meaning proposed in the early 1970s and Zadeh's (1965) fuzzy set theory (Kaltenböck, Mihatsch, \& Schneider, 2010). George (1997) views the term "hedge" as "one of the slightly facetious, creative terminological innovations that we owe to the revolutionary spirit of American linguistics in the early seventies of this century" (p. 21). Moreover, the concept of hedging can be defined in different ways in accordance with those fields but the contended issues it addresses are related and interdependent. The meaning of this term itself may pose some pragmatics and discourse analysis challenges between everyday uses of the term and its uses in the linguistic literature. For instance, in a contemporary usage when we say "to hedge a question" it means to avoid answering of a question, it may refer to commitment or protection as in "to hedge against" means to protect it (Collins, 1987).

Furthermore, Lakoff' (1972) clears the ground on the pragmatics perspectives of hedges markers in his view on the concept of hedging. He is primarily concerned with logical properties of linguistic expressions that are basically on the speech act theory. On the basis of his view, hedges play roles in performative utterances. In this sense hedges obviously, interact with felicity conditions for utterances and with rules of conversation. For Lakoff (1972) hedges are regarded as logical properties of linguistic expressions (such as kind of, sort of, strictly speaking) capable of making the concepts fuzzier or less fuzzy for their diagnostic value in analysing the semantics of the expressions by modifying the force of speech and demarcating the category boundaries of a concept. Shortly afterward, Fraser (1975) introduces the concept of "hedged performative" the idea which views "hedging as a rhetorical strategy and necessary pragmatic competence of speakers". Fraser regards model verbs as major elements used as hedge performatives (Pisanski \& Zlatnar, 2016).

Henceforth, the concept of "hedge" was fully conceptualised as linguistics element in the domain of pragmatics in the year 1978 from the work of Brown and Levinson (Kaltenbock, Mihatsch, Schneider 2010). Hedges are considered as a crucial aspect of linguistics elements used to mark discourse and their functions can have high effects in social interaction, as elements conveying fuzziness in meaning relations and markers of the level of certainty in a proposition as well as the forceful rhetorical strategies (Boncea, 2014).

Moreover, from the pragmatic perspectives, Brown and Levinson (1978) argue that hedges are not limited to the content or on the explicit performative expressions but also act "on illocutionary force and speaker commitment in general". According to these scholars "hedges" are linguistics elements used by speakers as means to show politeness or vagueness and precision in order to make a statement weaker or stronger, precise and clear. That is why they are termed by some scholars as markers of positive politeness. Hedges are the essential features of English for the academic purposes. They are the linguistic elements that are used to mark a discourse and indicate vagueness, precision, mitigation, and certainty. This will enable academic writers to build up confidence in their wiring by clearing the doubt or indicating the precise claim in their statements and put the reader at ease (Sedaghat, \& Biria, \& Amirabadi, 2015). Hence, hedges are expressions employed by speakers as means to modify the force of speech acts (Boncea, 2014).

\subsection{Modal Auxiliary Verbs}

Modal verbs belong to the words category known as auxiliary verbs whose meanings cannot stand on their own. They are used in conjunction with other main verbs to make an assessment, judgment, or interpretation of what we are speaking or writing about, or express our attitudes (Parrot, 2004). These include a semi-closed set of nine auxiliary verbs (will, should, can, could, may, might, shall, should, must) (Leech, 2014). According to the study conducts by Mindt (1995) would, could and will are the three most frequent modal verbs of all modal occurrences in his corpus. Modal verbs are also used by communicators through speaking or writing to express their attitude towards the world and to show their readiness, especially through two main semantic functions deontic meanings and epistemic meanings. The core "deontic" meanings include expression used to show "obligation", "intention", ability, necessity, possibility, "permission" or and logical deduction, disapproval about the phenomena they are addressing or discussing, while "epistemic" meanings include expressions used to indicate the truth conditions and assessment of degrees of certainty (Quirk, Greenbaum, Leech, \& Svartvik, 1985). Moreover, another sub-class of modal auxiliary verbs are called semi-modal verbs (Parrot), periphrastic (Westney, 1995) marginal modals (Quirk et al., 1985), quasi-auxiliaries (Joos, I968), these are usually modal in meaning not in form, as they are formed of two or three words. They also form affirmatives, negative and questions in different ways with pure modal verbs, and fulfill suppletive syntactic roles. They are claimed to form a considerable striking feature of present-day English (Kennedy, 2002).

One of the typical difficulties poses by modal verbs is the multiplicity of meaning. Most modal verbs have more than one meaning or function. Thus, the meaning of a modal verb is usually determined only by the context it occurs, which makes it clear which meaning is intended (Parrot, 2004; Leech, 2014; Suzuki, 2018). Quirk et al. 
(1985, p. 74) add that "most of the modal auxiliary verbs are polysemous and several have similar core meanings (e.g. Can is used for marking ability, possibility, and permission, must, should and ought to can each express obligation)".

For instance, different functions of modal verbs are indicated in a bracket in the following statements:

He can dance. (Ability)

May we start now? (Permission)

I may be there late. (Possibility)

May you live prosperous life! (Wish and hope)

You ought to be more decent. (Obligation)

The players should be home soon. (Logical deduction)

Shall we contribute? (Offering)

Shall I send later? (Suggesting)

Who shall we consult to assist us? (Seeking for advice or suggestions)

That must be true. (Certainty)

That will be true. (Probability)

They will try to say words before knowing their meanings. (Disapproval)

Parrot (2004) construes that in some occasions, the meaning of modal verbs can be made clear in the case of spoken language by intonation and "tone of voice" of the speaker. For example, the modal verb "might" in the following statements.

You might talk to him. (Possibility)

YOU MIGHT talk to him. (Disapproval)

You might have talked to him. (Possibility)

YOU MIGHT have talked to him. (Disapproval)

\subsubsection{Modal Verbs Hedging}

The hedging and modality are terms closely related in terms of their roles in semantic and pragmatic discourse. They are linguistics features used to determine the speakers' commitment to what they say or write and their sense of perceiving what others say or write (Fairclough, 2003). Hedging is concerning the fuzziness and certainty of the proposition while modality conveys the degree of certainty in a proposition (Hyland, 1996; Hardjanto, 2016). There is a strong relationship between hedges and modal verbs with respect to epistemic meanings conveying, politeness, obligation, and intention (Yunus, Suad, \& Rashid, 2016). In this sense, the two terms can be used interchangeably. For instances, considering the pragmatic function of hedges as linguistics elements that modify the level of certainty to the truth value of expressions modal verbs may, must are typical examples. Henceforth, modal verbs can convey different hedges meanings depending on the context they are used and the discourse they are represented. Markkanen and Schröder, (1997) construe that in some cases the modal verbs with deontic meaning can be interpreted as hedges. For example, the modal verb "would" can be taken as a hedge when it is used to make proposition non-categorical. Preisler (1986) posits that modal verbs can pose communicative problems due to their pragmatic functions which can be given interpersonal interpretations. Markkanen and Schröder (1997) establish two ways in relating modal verbs especially those that denoting epistemic meaning and hedges: is either we view modality as the wider concept comprising "hedges" or inversely, seen hedging as an "umbrella term" and "modality is part of it".

Furthermore, the idea of "hedges performatives" is relevant in discussing the relationship between hedging and modality (Pisanski \& Zlatnar, 2016). In this sense, modal verbs constitute a form of hedges used to modify "the speaker's commitment to the truth-value of a whole proposition, not gist the category membership of a part of it, (Markkanen \& Schröder, 1997, p. 7)". In the same vein, Frasser (1975) asserts that "modal" and "semi-modal verbs" can be considered as forms of hedged performatives when they are used to convey an "illocution act". Frasser conception is however limited to only two prepositional phrases "kind of", and "sort of". Meanwhile, the present study concerns the uses and functions of two primary modal auxiliary verbs "will" and "shall".

\subsection{Epistemic Modal Auxiliary Verbs}

Scholars have different views on the categorization of modality. For examples, modality can be classified into: intrinsic modality and extrinsic modality (Quirk et al., 1985); mood and modality (Palmer, 2001; Depraetere \& Reed, 2006); root modality and epistemic modality (Coates, 1983); agent-oriented modality and epistemic 
modality (Bybee \& Fleishman, 1985; Heine, 1995); deontic modality, epistemic modality and dynamic modality, and so forth. Moreover, this study concerns ore with the epistemic modality in respect of modal verbs "will" and "shall". In general term, the term epistemic modality is a cognitive-pragmatic element which is used to convey a truth value of a proposition (Palmer, 2014). In other words, "modality" is a linguistics element concerned with an explicit expression that conveys speaker's "commitment to the truth of the proposition" (Lyons, 1977, p. 797) Moreover, Lyons' conceptualisation of modality is not as explicit as that of Lakoff (1972) and other subsequent linguists who postulate that modality is explicit linguistic elements that modify part of the proposition. Stubbs' (1986) adds that modality has prosodic function concerning with illocutionary forces of the degree of commitment posed by lexical items.

\section{Method}

This study is a corpus-based analysis of linguistic elements. As an approach to linguistics analysis corpus linguistics by nature of its process, consists both elements of quantitative through frequency profiling and qualitative by analyzing the concordance lines (Rayson, 2003). Therefore, the study was based on the pragmatic points of view whereby any form of data "can contribute to an understanding of the issues at hand by depending on the context and complexity of the analysis seen as worthy of consideration" (Greene \& Caracelli, 1997). Again Sinclair (1991) lists certain linguistic criteria and characteristics that a corpus is assumed to have: quantity, quality, simplicity, and documentation.

\subsection{Setting}

The setting of this study is the Nigerian legal discourse whereas English is extensively used as legal lingua Franca. English is adopted as an official national language in the Nigerian Language policy despite having three major indigenous languages; Hausa, Yoruba, and Igbo. Obviously, this was as results of political and socio-cultural reasons and colonial tie with Great Britain. Henceforth, the English language is used as a medium of instruction at almost all levels of education, in bureaucracy, the media, national politics, science and technology, two legislative chambers, courts and other corporal companies and agencies.

\subsection{Sampling Procedures}

In this study, a document collection is utilised to source the data. As a corpus-based study, the data are collected through $\mathrm{h}$ two sources. The first source is the compiled constructed corpus (main-corpus) and the second source is the corpus of Law based on BNC (reference corpus) retrieved from online web-based concordance tool "Lextutor". In addition, the main corpus was constructed by the researchers from the data compiled from three Nigerian courts proceedings, the Federal High Court of Nigeria, Kano Judicial Division, National Industrial Court of Nigeria, Kano Judicial Division, the Federal Industrial High Court, Kano and The High Court of Justice of Kano of Nigeria, and legal reports. We give our constructed corpus working name NLC (Nigerian Law Corpus). On the other side, a corpus Law from British National Corpus (BNC) was used retrieved via online reference corpora concordance lines tool, Lextutor.

\subsubsection{Sample Size}

NLC namely (Nigerian Law Corpus) constructed and compiled by the researchers contains a total number of 540,013-word tokens. Meanwhile, BNC Law (reference corpus) contains a total number of 2.2 million word tokens. Moreover, two concordance tools are used to analyse the data of this study. One of the ethical issues in compiling NLC was seeking permission from the resources. Despite, the written permission, The Federal High Court of Nigeria asked us to exclude the names of people from the text collected. However, this did not deter us from getting our main target in the study.

\subsubsection{Data Analysis}

In this study, two corpus concordance tools are used to analyse the data "AntConc version 3.5" and "Lextutor version 7". The data generated from NLC $(540,013)$ are analysed using ANTCONC while LEXTUTOR is used to analyse the data retrieved via free online BNC Law $(2.2 \mathrm{~m})$. However, in the analysis phase, the frequencies of the keywords (will and shall) are determined and described quantitatively while keywords in the context (KWIC) are observed and discussed pragmatically. The computational importance of comparison between tag corpus (NLC) and reference corpus (BNC law) is helpful in improving the analytical standard in reporting the results. The primacy of comparison is to determine how lexical items (will and shall in this context) represent a particular genre and to determine whether particular lexical items are over-represented or lesser-represented. 


\section{Results and Discussion}

As mentioned in the methodology section two concordance tools are used to analyse the data collected in this study. The first concordance tool is AntConc software version 3.5. This software as a semi-automated free computer-aided tool is utilised to analyse the specialised Nigerian Law corpus developed by the researchers. All the files were saved as plain texts and then imported to the AntConc environment and analysed.

\subsection{The Frequency Distribution of the Occurrence of the Modal Verb "Will" and "Shall" in NLC and BNC Law}

The frequency counts of the results obtained from the analysis of the data are presented in the table below:

Table 1. The frequency table of the modal verbs WILL and SHALL in NLC and BNC Law

\begin{tabular}{llllll}
\hline S/No & Word Class Modal & \multicolumn{2}{l}{ Concordance Hits Frequency } & \multicolumn{2}{l}{ Concordance Hits Frequency Per Million } \\
\cline { 3 - 6 } & Verbs & NLC & BNC Law & NLC & BNC Law \\
1 & Will & 493 & 7,711 & 902 & 3,369 \\
2 & Shall & 401 & 1,348 & 734 & 589 \\
\hline
\end{tabular}

Table 1 presented the frequency distribution of the modal verbs "will" and "shall" as they occurred in NLC and BNC Law. As presented the total number of words token of the NLC is 546,313. Out of this number, the modal verb "will" appeared at 493 (excluding where it occurs as noun 63 instances) instances compared with "shall" which occurred at 401 instances. Based on this binary or head to head comparison will have the highest number of appearance than "shall" in NLC. On other hands, out of 2.2 million word tokens of BNC Law modal verb "will" was found to appear at 7,711 instances (excluding where it occurs as noun 183 instances) almost seven times high than modal verb "shall" which appeared at 1,348. Hence, the modal will is overused in both corpora; while there is an underuse of the modal "shall" in both the tagged corpus (NLC) and the reference corpus (BNC Law).

Furthermore, by looking at the results obtained from the tagged corpus (NLC 546,313) when compared to the reference corpus (BNC Law 2.2m) the modal verbs "will" and "shall" are foregrounded feature of NLC and BNC quantitatively. The results, however, revealed dramatic information concerning the concordance frequency hits per million of "will" and "shall" in both corpora (tag corpus and reference corpus). The verb "will" is over-represented in both NLC and BNC Law than the verb "shall". The frequency of modal verb "will" is standardised as (902 instances per million in NLC, and 3,369 instances per million, in NC Law) while the verb "shall" frequency is standardised as (734 instances per million in NLC and 589 instances per million in BNC). This showed a big difference in terms of representation, the verb "shall" is less represented or used in both NLC and BNC Law compare with the verb will. Moreover, the standardised frequency of token hits per million indicated that the verb "shall" is more apparently appeared in NLC than in BNC Law (NLC 734 and BNC 589).

\subsection{The Semantic Functions the Uses of Modal Verbs "Will" in the Legal Contexts (Concordance Lines Analysis)}

\section{1. "Will" can be used in the legal text to express insistence (strong volition)}

Extract 1. "Section 257 of the Constitution of the Federal Republic of Nigeria, 1999, is such that will accommodate the claims of the appellants as enumerated in their statement of claim before the lower court, the contention being 30 that subject to section 251 of 1999."

(NLC file 14)

In the extract 1 above the verb, "will" plays a role to indicate insistence, which is used to convey a strong volition. It is used to indicate uncompromising determination. Moreover, the force of certainty indicator in the statement above is equivalent to the "shall" and "most", the verb "will" has an obligatory force. In legal context "will" can be used to indicate obligation as equivalent to "shall" and "must", while in it conventionally use in general English to convey a future contingency rather than imposing an obligation or duty.

\section{2. "Will" can be used in legal text express obligation and duty}

In some cases the verb "will" can be used convey obligation or duty, similar in function to "must" and "shall" This is indicated in the extract 2 and 3 below:

Extract 2: "With regards to the P.O. dated 1st Feb. 16 we will be asking for an adjournment because the record of proceedings of the lower court which is material to this application is not ready." 
Extract 3: "For those conveyances on sale where the consideration (including any mortgage debt assumed) is less than 60,000, a certificate of value 'will' be required (see Chapter 2)."

(BNC Law)

\section{Will can be used to express intention (intermediate volition)}

Extract 4: "I find merit in this appeal. I will allow it and set aside the decision of the lower tribunal in which he dismissed the appellant's petition."

The modal verb "will" in the extract 4 indicates volition meaning relation that is the power of determining or making a decision or intention to do so in the future action. Volition meaning is the common usage of the verb "will" which is the "future implication of prediction" (Leech, 2014, p. 48). In this sense, the verb will mainly occur with first-person subjects (except in indirect speech) and it is used to convey semantic functions, such as "a promise", "a threat", "an offer or a shared decision". Moreover, the volitional force is an element that reinforces and justifies "a feeling that in the act of speaking, a decision is made, and that the fulfillment of the intention is guaranteed" (Leech, 2014, p. 48). As in the case of the above statement the judge uses the word "will" in the sense of "obligation" in a polite way and decision of justice taken by the rule of law. "To this extent, will (= "prediction") belongs to contexts similar to those of must (= "logical necessity")" (Leech, 2014). Henceforth, the modal verb will in this statement played a role of mitigation by alleviating the load of the statement. And it precisely indicated the position of the judge concerning the appeal. And at the same time as a legal discourse is concerned, it meant obligation that must be fulfilled for the justice.

\section{Will can be used to express prediction and logical necessity}

Extract 5: "It was thought exhibit CC the ministry informed the plaintiff that there will be no renewal. It is KASSEPPA that approves building plan."

(NLC file 11)

This modal verb will in the context above indicates a prediction in form of logical necessity. This is a kind of prediction usually use to indicate habitual or general prediction more appropriately use in scientific and quasi-scientific statements (Leech, 2014) it is used in legal context to indicate logical necessity with meaning similar to "must" and "shall". This is usually used in a conditional sentence. Logically the second sentence is an indicator of the cause of action.

\section{Will can be used to express prediction and logical necessity probability}

Extract 6: "Further inviting the Applicant by the 2nd-4th Respondents over this matter will certainly be in breach of his right to fair hearing as it is only a court of competent jurisdiction that is empowered to entertain such a dispute and I so hold."

(NLC file 6)

Extract 7: "Blackburn (C.A. 1968), Lord Denning said that while chief officers of police are answerable to the law, there are many fields in which they have a discretion with which the law will not interfere."

(BNC Law)

One of the conventional uses of the modal verb will is making a prediction of future action, while the force of certainty of the truth of the proposition would be made fuzzier and by indicating probability or the likelihood to happen or being true, with the verb "will". The modal verb will in the two extract 6 and 7 is used to convey the probability of the propositions.

\section{Will can be used to express mitigation and certainty}

Extract 8: "The above figures will also be deducted from the scores of both parties in Ido-Osi Local government and the calculation would be as follows: AC PDP Scores 3793 15,939 Less the 4971 12,937 Wards nullified 2,822 3,002."

(NLC file 1)

The modal verb will in the extract 8: above is also used to show mitigation, certainty, and obligation, it is used by the lawyer here to request for clarity of the calculation of votes in a case filed before the court challenging the victory of one electoral candidate. However, it could be argued that the lawyer here present his motion and appeal as he prayed for the judge to allow for recalculation of the votes. He used the word will instead of shall to persuade the judge but it meant shall. 


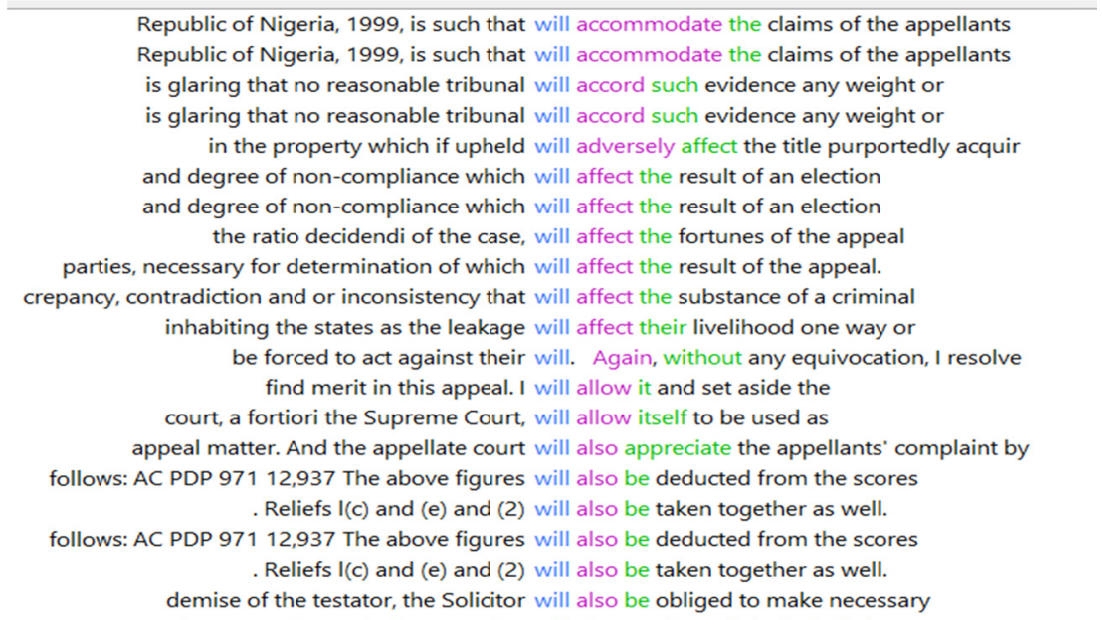

Figure 1. Samples of concordance lines of the use of WILL in NLC

Figure 1 above shows the concordance lines of the modal verb WILL in NLC analysed with AntConc software.

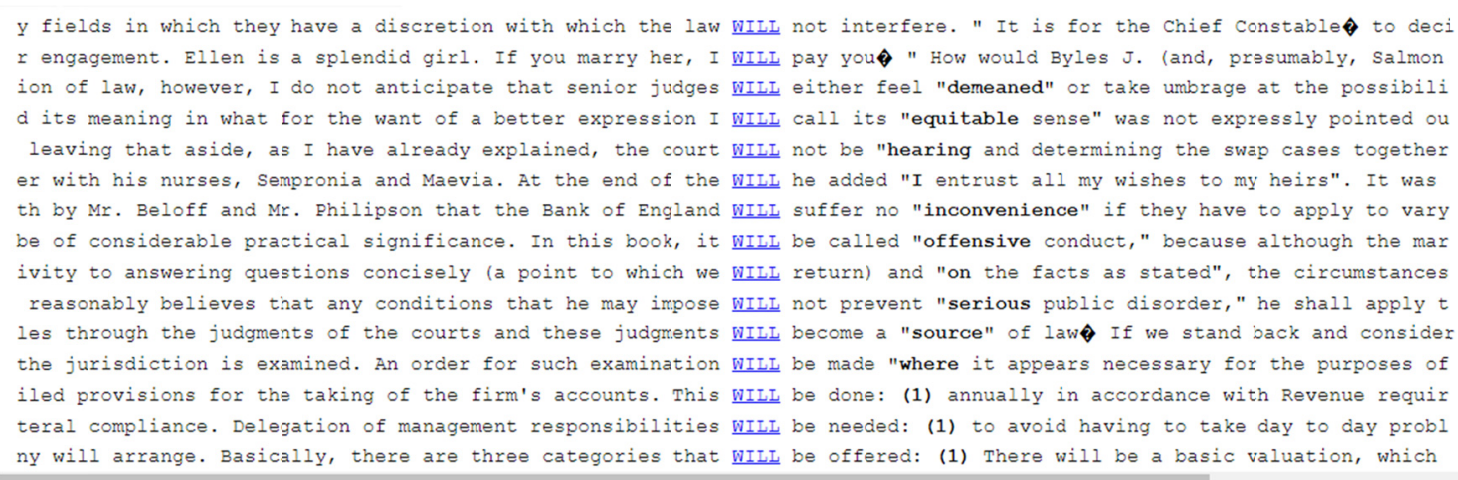

Figure 2. Samples of concordance lines of the use of WILL in BNC Law

Figure 2 above shows the concordance lines of the modal verb will as an analysed in the ANTCONC software.

\subsection{The Semantic Functions the Uses of Modal Verbs "Shall" in the Legal Contexts (Concordance Lines Analysis)}

Krapivkina (2017) construes that the modal verb "shall" has a dominant force in legal drafting, and regarded as one of the stylistic features of legal language as acknowledged by the UK Drafting Techniques Group (2008). The use of "shall" in legal discourse has been stigmatised by some scholars and the supporters of plain legal English for its multiple meaning which leads to ambiguity (Garner, 1995; Triebel, 2006; Krapivkini, 2017). "Shall" is considered as the troublesome element in the legal discourse, especially for the legal experts and the courts (Allen, 1995; Wydick, 1998). Williams (2011) as a supporter of plain legal English suggests that the modal verb "shall" can be replaced with "may", "will" and "must" to convey, Futurity, intention, and obligation. Based on Dickerson (1990) recommendation "shall" can be used in legal draft convey meanings such as obligation, duty and prohibition, "must" is suggested to indicate requirement and condition; "may" is required to show "discretionary authority", "may not" is implied "to negate discretionary authority" "shall not" is used "to create a duty not act" (for details see Indiana Drafting Manual 1999) (Krapivkina, 2017). Moreover, the supporters of legalese recommend using of "shall" to create all the semantic functions listed above. Below are the examples of the functions of "shall" taken from both the tagged corpus (NLC 546,313) and reference corpus (BNC Law $2.2 \mathrm{~m}$ ).

\section{Shall is used to impose rules and regulations (Legal duty or obligation)}

The modal verb "shall" is apparently used in legal texts to impose rules and regulations or in other words to convey duties and obligations (Leech, 2004; Krapivkina, 2017). 
Extract 9: "That you (name unmarked), Male, 39 years old is hereby sentenced to nine (9) Months imprisonment which time shall be calculated from the 31st day of May 2016 when you were first arrested."

(NLC file 3)

Extract 10: "On the issue that the action is statute barred because it was filed after 5 months after the order was given. It is the objector's counsel's submission that by O. 40 (4) of the rule of this court an application for Judicial Review shall be brought within 3 months of the date of occurrence of the subject of the application and there is no application for such extension of time for the application for judicial review."

(NLC file 7)

Extract 10: "The parties shall bear their respective costs in this appeal."

(NLC file 14)

Extract 11: "The goods SHALL be delivered and or the work performed on the date and at the place stated overleaf, and in accordance with the instructions specified overleaf, during normal business hours unless previously arranged otherwise. Delivery of goods SHALL be to the place specified overleaf and terms of carriage SHALL be as specified overleaf. 2.2 If for any reason, we are unable to accept delivery of the goods on or after the agreed delivery date, you will store the goods, safeguard them and take all reasonable steps to prevent their deterioration until delivery".

(BNC Law)

\section{Shall plus negative (not) can be used to express prohibition}

In this case "shall" imposes meaning similar to that of "must" in plain language (Bázlik \& Ambrus, 2009).

Extract 12: "Article 25 states that: (1) The carrier shall not be entitled to avail himself of the provisions of this convention which exclude or limit his liability, if the damage is caused by his wilful misconduct or by such default on his part as in accordance with the Law of the court seized of the case, is considered to be equivalent to wilful misconduct."

(NLC file 19)

Extract 13: "You SHALL NOT use any of the foregoing except in connection with our orders and you shall maintain the same in good condition and return them to us at any time on demand or otherwise automatically on completion of this order."

(BNC Law)

3. Shall plus negative (not) can also be used to convey a denial of permission

In this case "shall" conveys meaning similar to that of "may" in plain language. This has more apparently occurred in the Law of contracts (Williams, 2011; Martorana, 2012; Krapivkina, 2017).

Extract 14: "Paragraph 49(2) and (5) read as follows: (2) An application to set aside an election petition or a proceeding resulting therefrom for irregularity or for being a nullity, shall not be allowed unless made within a reasonable time and when the party making the application has not taken any fresh step in the proceedings after knowledge of the defect."

(NLC file 1)

Extract 15: "In this case the clause provided that the customer SHALL NOT be entitled to withhold payment of any amount due to the company under the contract by reason of any payment credit set-off or counterclaim".

(BNC Law)

4. Shall is used in the sense of "has the right to", to give permission, directory, suggestion, advice or request

In this sense "shall" conveys meaning equivalent to that of "may" (Aitken \& Butt 2004). The function of "shall" in this sense is also mentioned in the fifth edition of Black's dictionary (1983).

Extract 16: "We are grateful for the judgment just delivered. We shall be asking for cost our filing fees is N102, 420.00. We made 2 appearances in this suit. We shall be asking for the sum of N250, 000.00 against the Defendant...Court: Cost is assessed at N100, 000.00 against the Defendants assess".

(NLC file 9)

Extract 17: "Section 147(2) of the Electoral Act is also relevant and is hereby reproduced: 147(1) ... (2) If the tribunal or court determines that a candidate who was returned as elected was not validly elected on the ground that he did not score the majority of valid votes cast at the election, the election tribunal or the court as the case 
may be, shall declare as elected the candidate who scored the highest number of valid votes cast at the election and satisfied the requirements of the Constitution and this Act." (The Judge: Emphasis is mine)

(NLC file 1)

Extract 18: "We SHALL have the right of reasonable access to your premises to inspect such items while they are there."

(BNC Law)

Extract 19: "Further, a disposition between the separated spouses will rank as a transfer between the spouses so that the exemption is still available, as there is no requirement (in contrast to the capital gains tax legislation see p. 16) that the spouses $\boldsymbol{S H} \boldsymbol{A L L}$ be living together."

(BNC Law)

\section{Shall can be used as a basis for argument in court}

Extract 20: "The use of the word shall in the foregoing provisions, make the compliance compulsory."

(NLC file 1)

Extract 21: "By the use of the word "SHALL" as stated in the rules supra, it presupposes that briefs are mandatory requirements by all parties for effective prosecution of an appeal. A further confirmation is again signified by the use of the word "shall" which is provided for in the same order 17 rule 4(2) regarding the respondent's brief."

(NLC file 15)

In this above statements, the lawyer argued the use of the word shall is strongly showed the inevitability of the obligation that must be fulfilled. It indicates that in legal discourse the uses of either shall or will handle with seriousness and can be a basis of argument in the court.

Extract 22: "The word may use in the law does not have the compelling authority of the word shall; whatever the word "recommended" mean in the statute"

In the extract 22 also it indicated how lawyer presented his argument based on the uses of the two different modal verbs "may" and shall whereby he construed that the former have no have the compelling authority on the latter.

(NLC file 7)

Extract 23: "Sections 238, 239, 339 and 340 provide that the court "shall," on an application under those sections: The subsection echoes the language of subsection (3) by providing that the clients shall be treated "as entitled to" the appropriate proportion of the deposit."

(BNC Law)

\section{Shall can be used to express a precondition (Krapivkina, 2017); however, it has the obligatory force}

"Paragraph 1 (1) of the Practice Directions provides: 1. (1) All petitions to be presented before the tribunal or court shall be accompanied by a) List of all the witnesses that the petitioner intends to call in proof of the petition..."

(NLC file 14)

"If the Revenue accept that the court order or agreement between the parties created a settlement on the ground that the interests of the beneficiaries are not of the same quality as the wife has a right of occupation (see Booth v Ellard [1980] 1 WLR 1443) Taxation of Chargeable Gains Act, 1992, s225 provides that the gain accruing to a trustee on the disposal of settled property SHALL in effect be free from capital gains tax where during the period of ownership the house has been the only or main residence of the person entitled to occupy it under the terms of the settlement."

(BNC Law) 


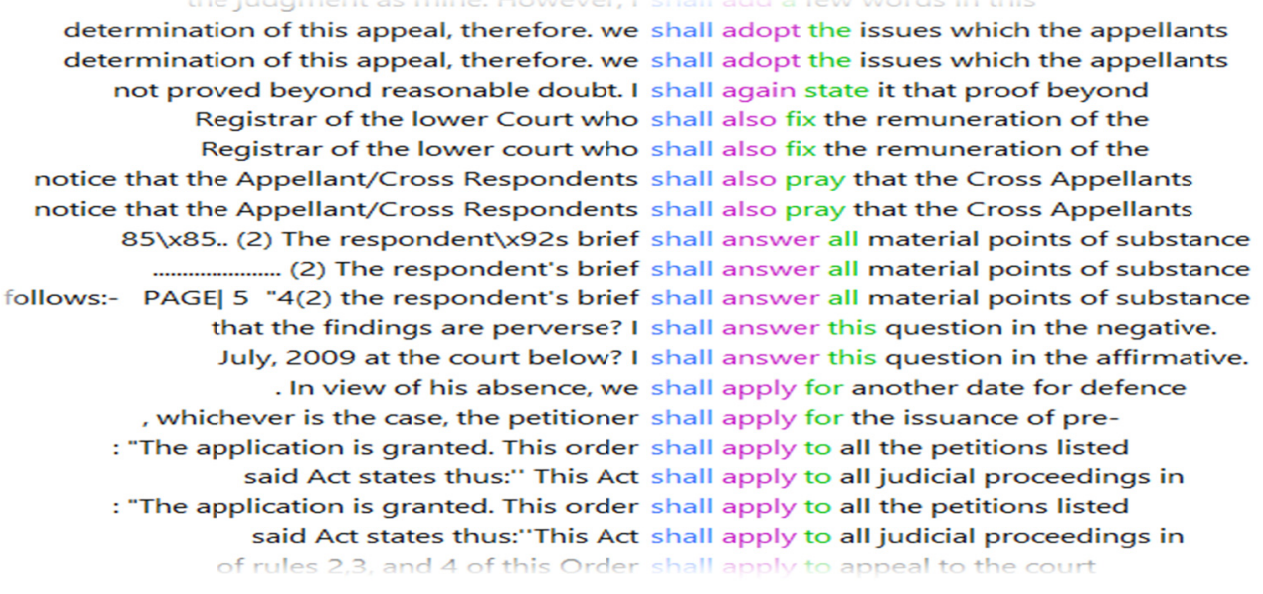

Figure 3. Samples of concordance lines of the use of shall in NLC

Figure 3 above shows, the concordance lines of the modal verb shall analysed with the AntConc software. Consequently, in the reference corpus, they both appeared nearly equal, with 1000 hits per million.

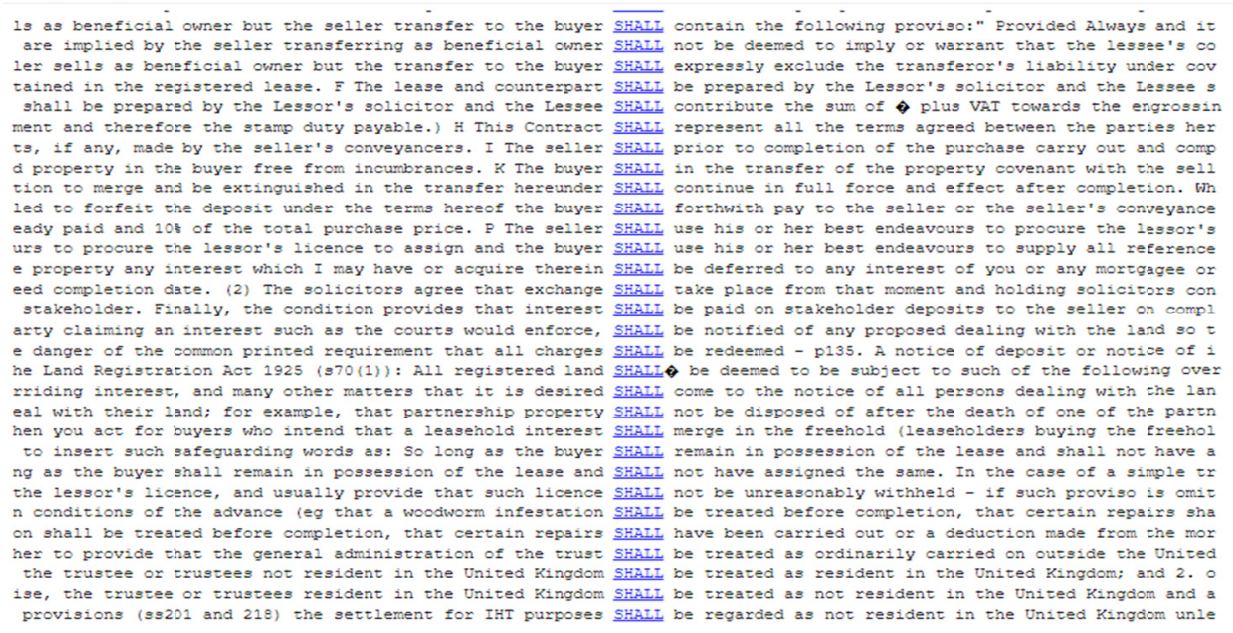

Figure 4. Samples of concordance lines of the use of shall in BNC Law

Figure 4 above shows the concordance lines of the modal verb will as an analysed in the ANTCONC software.

\section{Conclusion}

This study examined the semantic and pragmatic function of the two primary modal verbs "will" and "shall" as hedges in legal texts. Legal discourse is a genre characterised by the special language used to achieve precision, clarity, and persuasion. It is a practice of law to avoid ambiguity and polysemous words or phrases. However, the modal verbs "shall" and "will" are considered to be among the frequent features of legal discourse, despite having multiple of meaning relations semantically and pragmatically. Their diversity in meaning can cause ambiguity, fuzziness, and lack of precision which can frustrate legal provisions and difficult for laymen to interpret. Legal practitioners paid more attention to semantic and pragmatic functions of the modal verbs used in the legal discourse. As discussed in this study, the modal verbs "will" and "shall" can perform a number of semantic and pragmatic functions in legal discourse. It can be a major source for the lawyers to argue on a case as result of different functions of modal verbs. Moreover, unlike traditional views and pragmatic perspectives, modal verbs may be used differently in the legal discourse. Therefore, this study suggested that widest text should be analysed to identify the uses of all modal verbs in the general English and legal English. 


\section{References}

Ahmed, W. K., \& Maros, M. (2017). Using Hedges as Relational Work by Arab EFL Students in Student-Supervisor Consultations. GEMA Online J ournal of Language Studies, 17(1), 89-105. https://doi.org/10.17576/gema-2017-1701-06

Aitken, J. K., \& Butt, P. (2004). Piesse the element of drafting. Sydney: Lawbook.

Allen, R. (1999). Oxford pocket fowler's modern English usage. Oxford, UK: Oxford University Press.

Ashipu, K. B. C., \& Umukoro, G. M. (2014). A critique of the language of law in selected court cases in Nigeria. Mediterranean Journal of Social Sciences, 5(8), 622-627.

Bhatia, V. K. (1987). The language of the law. Language Teaching, 20(4), 227-234. https://doi.org/10.1017/S026144480000464X

Biel, $Ł$. (2017). Lexical bundles in EU law: The impact of translation process on the patterning of legal language. In G. Pontrandolfo (Ed.), Phraseology in Legal and Institutional Settings: A Corpus-based Interdisciplinary Perspective. New York, USA: Routledge.

Black, H. C., Nolan, J. R., \& Nolan-Haley, J. M. (1979). Black's dictionary. St. Paul, Minn.: West Publishing Co.

Blum-Kulka, S., \& Olshtain, E. (1984). Requests and apologies: A cross-cultural study of speech act realization patterns (CCSARP). Applied Linguistics, 5(3), 196-213. https://doi.org/10.1093/applin/5.3.196

Boncea, I. (2014). Hedging Patterns Used as mitigation and politeness strategies. Annals of the University of Craiova. Series: Philology, English, 2(1), 7-23.

Brown, P., \& Levinson, S. C. (1987). Politeness: Some universals in language usage (Vol. 4). Cambridge, UK: Cambridge University Press. https://doi.org/10.1017/CBO9780511813085

Bybee, J. L., \& Fleischman, S. (1995). Modality in grammar and discourse: an introductory essay. In J. L. Bybee \& S. Fleischman (Eds.), Modality in grammar and discourse (pp. 1-14). Amsterdam and Philadelphia: John Benjamins. https://doi.org/10.1075/tsl.32

Coates, J. (1983). The semantics of the modal auxiliary. London, UK: Croom Heim.

Collins (1987). Collins Cobuild English Dictionary. London, UK: Collins Publishers.

Danet, B. (1980). Language in the legal process. Law and Society Review, 14(3), 445-564. https://doi.org/10.2307/3053192

Depraetere, I., \& Reed, S. (2006). Mood and modality in English (pp. 269-290). https://doi.org/10.1002/9780470753002.ch12

Dickerson, R. (1990). Choosing between shall and must in legal drafting. Scribes Journal of Legal Writing, 1(1), 144-147.

Fairclough, N. (2003). Analysing discourse: Textual analysis for social research. New York, USA: Routledge. https://doi.org/10.4324/9780203697078

Fraser, B. (1975). Hedged performatives. In P. Cole \& J. L. Morgan (Eds.), Syntax and Semantics (Vol. 3, pp. 187-210). New York: Academic Press.

Georg, P. (1997). Hedging strategies in written academic discourse: Strengthening the argument by weakening the claim. Hedging and discourse: Approaches to the analysis of a pragmatic phenomenon in academic texts, 24, 21.

Gibbons, J. P. (2013). Language and the Law. New York, USA: Routledge.

Greene, J. C., \& Caracelli, V. J. (1997). Defining and describing the paradigm issue in the mixed-method evaluation. New directions for evaluation, 1(74), 5-17. https://doi.org/10.1002/ev.1068

Hardjanto, T. D. (2016). Hedging Through the Use of Modal Auxiliaries in English Academic Discourse. Humaniora, 28(1), 37-50. https://doi.org/10.22146/jh.v28i1.11412

Heine, B. (1995). Agent-oriented vs. epistemic modality. In J. Bybee \& S. Fleischman (Eds.), Modality in Grammar and discourse (pp. 17-53). Amsterdam: John Benjamins Publishing Company. https://doi.org/10.1075/tsl.32.03hei 
Holland, J., \& Webb, J. (2013). Learning legal rules: a students' guide to legal method and reasoning. United Kingdom: Oxford University Press. https://doi.org/10.1093/he/9780199657490.001.0001

House, J., \& Kasper, G. (1981). Politeness markers in English and German. Conversational routine, 157185. https://doi.org/10.1515/9783110809145.157

Hyland, K. (1996). Nurturing hedges in the ESP curriculum. System, 24(4), 477-490. https://doi.org/10.1016/S0346-251X(96)00043-7

Ibrahim, B., Yusof, B. Y., Ahamd, N. S., \& Omar, N. M. B. S. (2016). Sentence fragmentation in the writing of senior secondary school students of Gwale, Kano, Nigeria. Scholars Journal of Arts, Humanities and Social Sciences, 4(9A), 992-1000.

Joos, M. (1968). The English verb: form and meanings. Madison Wisconsin, USA: University of Wisconsin Press.

Kaltenböck, G., Mihatsch, W., \& Schneider, S. (Eds.). (2010). New approaches to hedging. United Kingdom: Emerald Group Publishing Limited.

Kamal, A. (2010). Language for Academic Purposes: A Learning-Centred Approach. Nigeria: Ahmadu Bello University Press Ltd.

Kennedy, G. (2002). Variation in the distribution of modal verbs in the British National Corpus. Using corpora to explore linguistic variation, 73-90. https://doi.org/10.1075/scl.9.06ken

Kjær, A. L. (2007). Legal translation in the European Union: A research field in need of a new approach. Language and the Law, 1(1), 69-95.

Kopple, W. J. V. (1985). Some exploratory discourse on metadiscourse. College Composition and Communication, 36(1), 82-93. https://doi.org/10.2307/357609

Krapivkina, O. A. (2017). Semantics of the verb shall in legal discourse. Jezikoslovlje, 18(2), 305-317.

Lakoff, G. (1972). Hedges: A Study in meaning criteria and the logic of fuzzy concepts. In Papers from the Eight Regional Meeting, Chicago Linguistic Society, 1(1), 83-228.

Leech, G. N. (2014). Meaning and the English verb. New York, USA: Routledge. https://doi.org/10.4324/9781315835464

Lyons, J. (1977). Semantics. Cambridge, UK: Cambridge University Press. https://doi.org/10.1017/CBO9781139165693

Markkanen, R., \& Schröder, H. (1997). Hedging and discourse: Approaches to the analysis of a pragmatic phenomenon in academic texts (Vol. 24). Walter de Gruyter. https://doi.org/10.1515/9783110807332

Martorana, V. R. (2014). A guide to contract interpretation. London, UK: Reed Smith LLP.

Mattila, H. E. (2016). Comparative legal linguistics: a language of Law, Latin, and modern lingua Francas. New York, USA: Routledge. https://doi.org/10.4324/9781315573106

Mellinkoff, D. (1963). The language of the law. Boston: Little Brown and Company.

Mindt, D. (1995). An empirical grammar of the English verb: modal verbs. Berlin: Cornelsen.

Nuyts, J. (2001). Epistemic modality, language, and conceptualization: A cognitive-pragmatic perspective (Vol. 5). Amsterdam, Netherlands: John Benjamins Publishing. https://doi.org/10.1075/hcp.5

Palmer, F. R. (2001). Mood and modality. Cambridge, UK: Cambridge University Press. https://doi.org/10.1017/CBO9781139167178

Palmer, F. R. (2014). Modality and the English modals. New York, USA: Routledge. https://doi.org/10.4324/9781315846453

Parrot, M. (2004). Grammar for English language teachers. Cambridge, UK: Cambridge University Press.

Pisanski, A. P., \& Zlatnar, M. M. (2016). Translating hedging devices in news discourse. Journal of Pragmatics, 102, 1-12. https://doi.org/10.1016/j.pragma.2016.06.009

Preisler, B. (1986). Linguistic sex roles in conversation. Berlin: Mouton de Gruyter. https://doi.org/10.1515/9783110862973

Quirk, R., Greenbaum, S., Leech, G., \& Svartvik, J. (1985). A Comprehensive Grammar of the English Language. New York, USA: Longman. 
Rahman, M. (2015). English for specific purposes (ESP): A holistic review. Universal Journal of Educational Research, 3(1), 24-31.

Rayson, P. (2003). Matrix: A statistical method and software tool for linguistic analysis through a corpuscomparison. Doctoral dissertation, Lancaster University.

Schröder, H., \& Zimmer, D. (1997). Hedging research in pragmatics: A bibliographical research guide to hedging. Hedging and discourse: Approaches to the analysis of a pragmatic phenomenon in academic texts, 1(2), 249-271. https://doi.org/10.1515/9783110807332.249

Sedaghat, A., Biria, R., \& Amirabadi, Y. A. (2015). Cross-cultural analysis of hedges in Persian and English editorial columns. International Journal of Language Learning and Applied Linguistics World, 8(1), 37-50.

Sharndama, E. C., \& Jauro, L.B. (2014). Comparative analysis of voices in professional and popularized legal texts. International Journal of English Language and Humanities (IJELLH), 2(4), 259-268.

Sinclair, J. (1991). Corpus, Concordance, Collocation: Describing English Language. Oxford: Oxford University Press.

Stubbs, M. (1986). A Matter of Prolonged Field Work: Notes Towards a Modal Grammar of English. Applied Linguistics, 7(1), 1-25. https://doi.org/10.1093/applin/7.1.1

Suzuki, D. (2018). The semantics and pragmatics of modal adverbs: Grammaticalization and (inter) subjectification of perhaps. Lingua, 1(1), 1-14. https://doi.org/10.1016/j.lingua.2018.06.003

Vass, H. (2017). Lexical verb hedging in legal discourse: The case of law journal articles and Supreme Court majority and dissenting opinions. English for Specific Purposes, 48, 17-31. https://doi.org/10.1016/j.esp.2017.07.001

Westney, P. (1995). Modals and periphrastic in English. Tubingen: Niemeyer.

Williams, C. J. (2011). Legal English and plain English: An update. ESP Across Culture, 8(2), 139-151.

Wydrick, R. C. (1998). Plain English for lawyers. Durham, North Carolina: Carolina Academic Press.

Yunus, K., Mohamad, M., \& Waelateh, B. (2016). The breadth of receptive vocabulary knowledge among English major university students. Journal of Nusantara Studies, 1(1), 7-17. https://doi.org/10.24200/jonus.vol1 iss1pp7-17

Yunus, K., Su'ad, A., \& Rashid, R. A. (2016). Colligations of prepositions: Essential properties of legal phraseology. International Journal of Applied Linguistics and English Literature, 5(6), 199-208.

Zadeh, L. A. (1996). Fuzzy sets. Fuzzy Sets, Fuzzy Logic, and Fuzzy Systems: Selected Papers by Lotfi A Zadeh, 1(1), 394-432. https://doi.org/10.1142/9789814261302_0021

\section{Corpora}

British National Corpus $(\mathrm{BNC}) \sim$ Law 2.2 million-word tokens $\sim$ accessed from https://www.lextutor.ca/conc/eng/

Nigerian Legal Corpus (NLC) 546,313-word tokens Compiled by the authors (offline)

\section{Copyrights}

Copyright for this article is retained by the author, with first publication rights granted to the journal.

This is an open-access article distributed under the terms and conditions of the Creative Commons Attribution license (http://creativecommons.org/licenses/by/4.0/). 